\title{
Embedslægevæsenet i hertugdømmet Slesvig indtil 1864
}

\author{
af Tage Grodum
}

Embedslæge Tage Grodum, Aabenraa har i 1986, 1987 og 1988 i tre store afhandlinger i Dansk medicinhistorisk årbog redegjort for embedslægevæsenets historie i hertugdømmerne Slesvig og Holsten. Dette emne har hidtil ikke været fyldigt behandlet $\mathrm{i}$ historisk sammenhæng. Artiklen her er en sammenfatning af de foregående års undersøgelser.

Embedslæger har altid været offentlig ansatte læger, der har skullet udføre bestemte opgaver. Deres aflønning har derfor fundet sted fra offentlige kasser. I dag er embedslægerne statsansatte og kongeligt udnævnte, og således var det også tidligere. I hertugdømmerne Slesvig og Holsten var embedslægerne aflønnet af de (statslige) amters og købstædernes kasser. Tidligere tiders embedslæger tituleredes fysici, den stillingsbetegnelse, der fortrinsvis også vil blive anvendt $i$ det folgende.

Kong Christian V (1670-1699) udstedte 4. december 1672 en Medicinal- og apotekerforordning for "Kongens Riger og Lande«.' Denne skulle blive den grundlæggende lovgivning for medicinalvæsenet $\mathrm{i}$ kongeriget $\mathrm{i}$ næsten 240 år og $\mathrm{i}$ hertugdømmerne $\mathrm{i}$ ca. 180 år. Da embedslægegerning altid har hvilet på lovgivning, fik forordningen fra 1672 meget stor betydning for denne gruppe læger.

\section{Embedslægevæsenets oprindelse og de første fysici}

Tanken om for offentlige midler at ansætte læger i det danske monarki synes at være udsprunget samtidig med reformationen. Ideen var ikke at ansætte embedslæger med de funktioner, som siden blev tillagt dem, men derimod udelukkende at sørge for kvalificerede behandlere til befolkningen.

På Herredagen 1526 i Odense foreslog kong Frederik I (1523-1533), at der fra udlandet skulle indkaldes læger og apotekere til betjening af befolkningen i Danmark. ${ }^{2}$ Men da man var klar over, at det ville koste staten penge, idet disse læger måtte offentlig ansættes, kom der intet ud af forslaget, selv om man skønnede, at det ville være nok med én læge i Jylland og én på Sjælland.

I fortalen til »En liden Bog om Menniskens Vand/oc anden Naturlig Affgang« skriver Henrick Smid i Malmø 1557: „Vor kiæriste naadige Herre/ 
Kong Christian giør oc stor flidt der til/som ieg haffuer forestaaet/at hans Kongelige Maiestet ville det gierne saa skicke/at i huert Biscops Stict her udi Riget skulde vere en Lærder oc forfaren Doctor i Lægekonst/til huilcken mand kunde haffue sin tilfluct om nogen finge nogen Siugdom/oc met hans Konstis hielp beredde sit Liff/om det vaare Guds gode vilie. « $^{3}$

Kong Christian III (1534-1559) nærede altså samme ønske som sin fader, men ønskede en læge $i$ hvert af landets stifter. At Christian III virkelig fulgte sine ideer op, fremgår af nogle breve, han udstedte i 1545 angående byerne Ribe og Viborg. ${ }^{4}$ Ribe fik besked om, at et præbende og kanonikat ved domkirken skulle forbeholdes en doctor eller licentiat i medicin, som skulle bo i Ribe, og såfremt der ikke var et præbende eller kanonikat ledigt, måtte domkapitlet aflønne vedkommende svarende til en kannik. I Viborg testamenterede kongen Thestrupgård til fattighospitalet på betingelse af, at hospitalsforstanderen årligt skulle udrede 50 daler til en doctor eller licentiat i medicin med bopæl i Viborg, indtil domkirken kunne forestå aflønningen i form af en bolig og kannikeløn.

Ingen af de to stifter fik dog straks en læge. Først omkring 1555 kom en læge til Viborg, ${ }^{5}$ og omkring 1580 var der en læge i Ribe. ${ }^{6}$ En læge omtales i Odense omkring 1549, 1557 kom der en læge til Bergen ${ }^{8}$ og 1568 var der også læge i Roskilde.9 Først i Kong Christian IV's regeringstid kendes der fysici i alle rigets stifter foruden en stadsfysikus i København. Christian IV (15881648) interesserede sig blandt mange andre gøremål også for sine undersåtters helbredsforhold, og i 1619 udstedte han den forste medicinalforordning i Danmark. Den kom dog kun til at fungere $i$ hovedstaden og foreskrev intet specielt om embedslægepligter. ${ }^{10}$ Datidens embedslæger var først og fremmest offentlig ansatte behandlere, der med en universitetsuddannelse skulle være en lægelig kvalitetshøjnelse set $\mathbf{i}$ forhold til datidens andre sygdomsbehandlere såsom barberkirurger, broksnidere, stærstikkere, skarprettere samt kloge mænd og koner.

\section{Embedslægevæsenets opståen i Slesvig}

Mens der $\mathrm{i}$ det »egentlige Danmark« efterhånden ansattes fysici $\mathrm{i}$ alle landets stifter, og man derved fulgte de intentioner, Christian III havde haft, kunne dette på grund af de administrative forhold ikke lade sig gøre i hertugdømmet Slesvig. Størstedelen af hertugdømmet hørte under bispestolen i byen Slesvig, men den vestlige del af Nordslesvig hørte under Ribe-bispen, og Als samt Ærø hørte under biskoppen i Odense. ${ }^{11}$ Desuden var hertugdømmets verdslige administration opdelt "på tværs« af den gejstlige i kongelige dele, Gottorpske 
dele, de små hertugdømmer i Hertug Hans den yngres slægt, og endelig var der de nørrejyske (eller kongerigske) enklaver i Vestslesvig. Forvaltningen af disse områder var forskellig - og havde ret til at være det. ${ }^{12}$

Offentlig ansættelse af læger og sidenhen fysici fandt derfor sted på et senere tidspunkt i hertugdømmet Slesvig end i det øvrige Danmark, og amterne blev de administrative enheder, fysikatsdistrikterne i Slesvig kom til at bestå af.

Den forste offentlig ansatte læge, der kendes i hertugdømmet er dog en stadsfysikus ved navn Johannes Lysius (1567-1621), der i 1603 ansattes af magistraten i Flensborg. Christian IV havde året før udtalt forbavselse over, at monarkiets næststørste by hverken havde stadslæge eller apotek. Det var for at sikre byens borgere egentlig lægehjælp, at der i den kongelige by ansattes en universitetsuddannet læge. ${ }^{13}$ Siden var der til omkring 1685 stadsfysici i Flensborg, der således ikke var ansat til at virke i landdistrikterne omkring byen - men givetvis gjorde det.

1648 omtales en medicinsk kandidat Johannes Rager som stadsfysikus i Ekernforde, men andet har hidtil ikke kunnet opspores om hverken denne læge eller embedet. ${ }^{14}$

I Tonning nævnes omkring 1685 en land- og stadsfysikus, men hans navn kendes ikke, og det vides ikke, om stillingen i det hele taget var besat, eller hvor længe den eksisterede. ${ }^{15} 1720$-21 var der en stadsfysikus i Tønning, ${ }^{16}$ men først fra 1739 findes der en kontinuerlig række af fysici for hele Eidersted. ${ }^{17}$

Først i slutningen af 1600-tallet begyndte der at blive oprettet fysikusembeder omfattende både købstæder og landdistrikter. Det må formodes, at det var medicinalforordningen fra 1672, der inspirerede hertil. Ganske vist fik forordningen aldrig den tilsigtede virkning i hertugdømmerne Slesvig og Holsten, måske fordi den indgik i Christian V's Danske Lov fra 1683 og ikke i Jydske Lov, der var lovgrundlaget i hertugdømmet Slesvig.

\section{Autorisationsproblemer og universitetet i Kiel}

Straks i 1672-forordningens $\S 1$ var der indbygget problemer for lægevæsenet $i$ hertugdømmerne. Der stod, at de som ønsker at praktisere wi nogen Bye eller Sted, i begge Kongelige Riger og Lande« eller udgiver sig for at være medicinsk doktor, skal ikke have lov til at praktisere eller føre betegnelsen medicinsk doktor, før de over for det medicinske fakultet i København har dokumenteret deres faglige kvalifikationer. ${ }^{18}$ Det betød, at læger, der var uddannet ved Kiels universitet, oprettet i 1665 af hertug Christian Albrecht af Gottorp, ${ }^{19}$ ikke umiddelbart kunne virke i deres fag. Universitetet i København skulle først give sin tilladelse. Det var formentlig en af grundene til, at universi- 


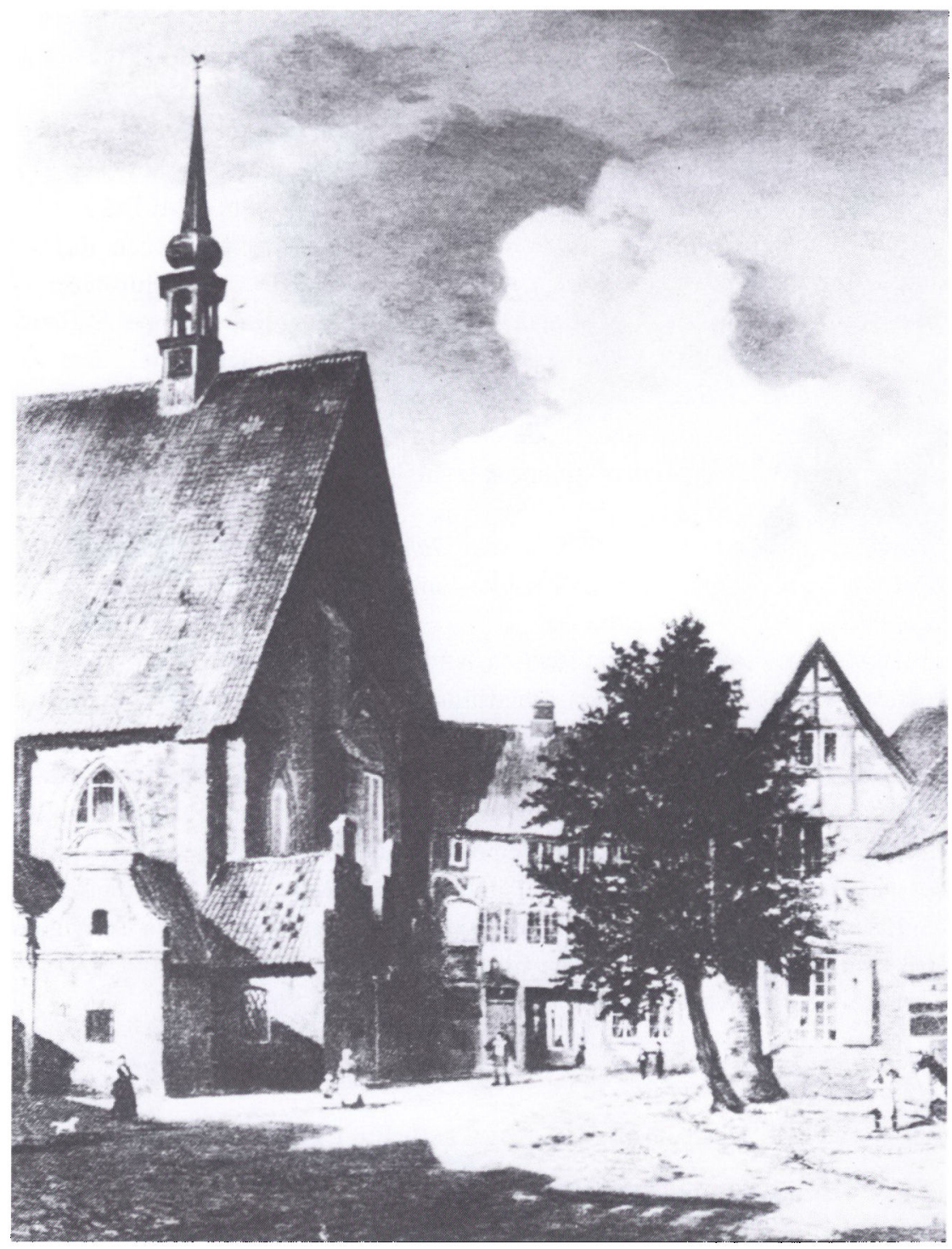

Helligåndskirken $i$ Kiel med indgangen til klostergården og den aldste universitetsbygning, som var en del af det tidligere kloster. (Maleri af Adolf Lohse, midten af 19. dirh.) Både kirken og klosterbygningerne blev odelagt ved luftbombardement under 2. verdenskrig. 
tetet i Kiel førte en hensygnende tilværelse med faldende studentertal i det 17. og 18. århundrede.

Forordningen fra 1672 skulle - som næunt - være gældende wi Kongens Riger og Lande«, således også i hertugdømmet Slesvig, både i de kongelige og i de hertugelige dele. Men først efter Inkorporationen $1721,{ }^{20}$ hvorved hertug Carl Friedrich af Gottorp (1700-1739) efter at have holdt med Sverige i Den store nordiske Krig måtte afstå sine slesvigske besiddelser til den danske konge Frederik IV (1699-1730), skulle mulighederne for gennemførelse af medicinalforordningen blive betydelig større. Alligevel var det nødvendigt $\mathrm{i}$ 1749, men antedateret til 15 . august 1746 , at udstede et reskript med den hensigt at erindre om, at 1672-forordningen krævedes gennemført også i hertugdømmerne. ${ }^{21}$ Ganske vist stod der i 1746-reskriptet, at forordningen fra 1672 »i Henseende til Hertugdømmerne på nogle Punkter er blevet ændret og forbedret«, men reskriptet af 1746 refererede nøje til de enkelte paragraffer i forordningen fra 1672 .

Af ændringer foreskreves, at den, der ville virke som praktiserende læge $\mathrm{i}$ hertugdømmerne, først skulle fremstille sig personligt for distriktsfysikus og aflægge en prøve for sin duelighed. Når det var sket, skulle den ansøgende læge over for praksisstedets øvrighed aflægge ed på, at han ville overholde galdende medicinallovgivning herunder forordningen fra 1672 . Først derpå kunne lægen få lov til at praktisere. Dette gjaldt også for hertugdømmernes egne indbyggere, som måske havde studeret medicin i Kiel eller i udlandet, men ikke i København. ${ }^{22}$ Denne lempelse for at opnå autorisation som læge må have været en lettelse for universitetet $\mathrm{i}$ Kiel.

1738 var der i Altona oprettet et gymnasium, Christianeum, som var en mellemting mellem en lærd skole og et universitet, idet dets "overbygning" ("Selecta«) bestod af et teologisk, flosofisk, retsvidenskabeligt og medicinsk fakultet. Det var tænkt at skulle være en kongelig pendant $i$ hertugdømmerne til det gottorpsk-hertugelige universitet $\mathrm{i}$ Kiel og fik derfor tillagt visse privilegier. Således bestemtes ved patent af 11 . maj 1744, at kongens undersåtter i hertugdømmerne - det vil sige fra hele hertugdømmet Slesvig og de kongelige dele af Holsten - skulle studere der de første 1-2 studieår for siden at kunne opnå højere embeder. ${ }^{23}$

Christianeum i Altona synes således at være tænkt ligestillet med universitetet i København - også set $\mathrm{i}$ relation til lægers autorisation i henhold til medicinalforordningen fra 1672. Men denne ligestilling kan - såfremt den i det hele taget blev bragt $\mathrm{i}$ anvendelse - kun have haft betydning $\mathrm{i}$ de få år, der hengik til reskriptet dateret 15.8.1746 udstedtes i 1749 .

Yderligere lettedes eksistensen for Kiels universitet ved gennemførelsen i 1773 af Mageskiftetraktaten, hvorved gottorpernes holstenske besiddelser - 


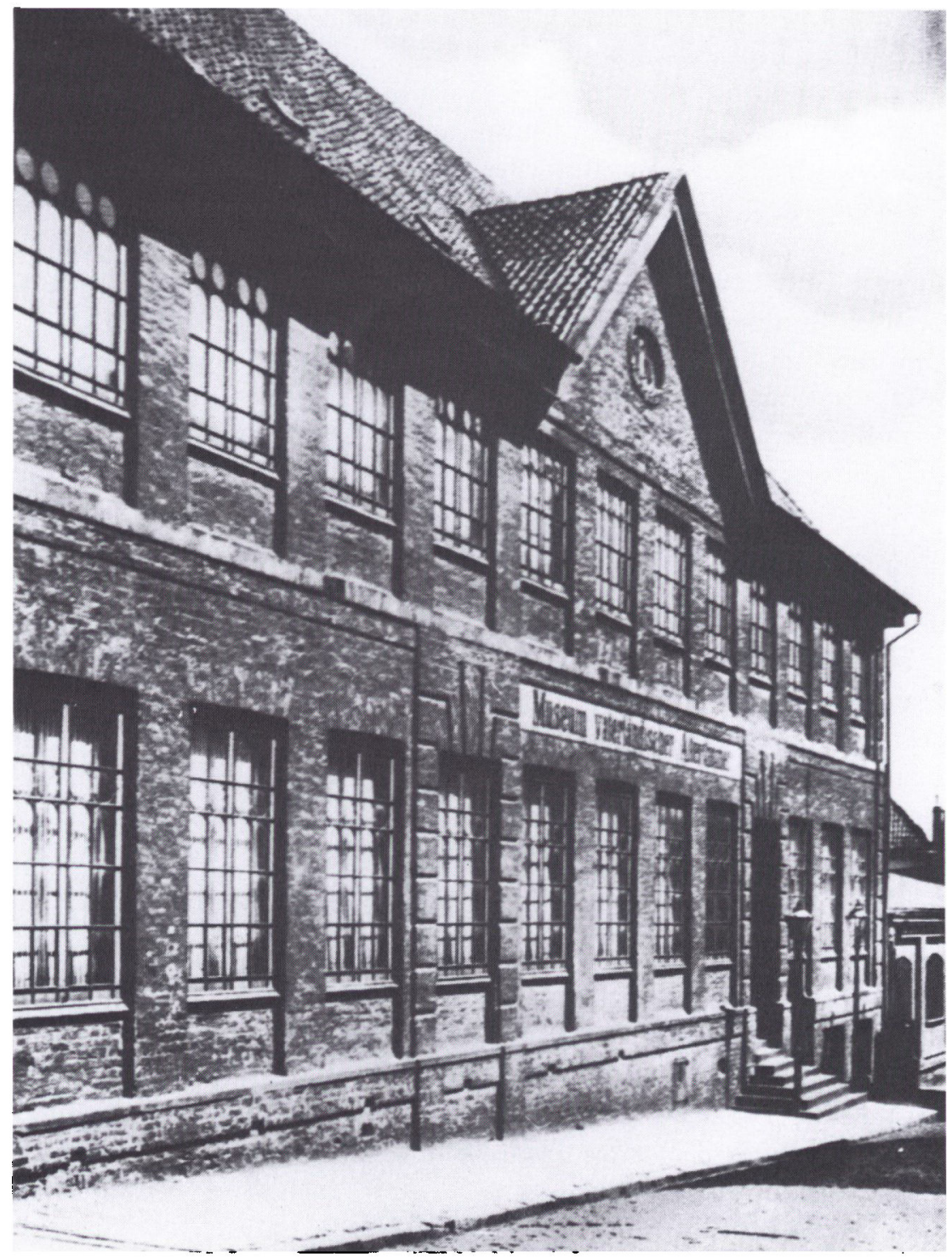

I 1768 fik Kiels universitet en ny bygning, tegnet af arkitekten Ernst Georg Sonnin. Siden blev den fra 1876 anvendt til Museum vaterländischer Altertümer. Den blev bomberamt og odelagt under 2. verdenskrig og eksisterer således ikke mere. 
herunder også byen Kiel - blev overdraget den danske konge. ${ }^{24}$ Men allerede i 1768 var der i al hemmelighed udstedt en forordning om, at alle akademikere, der ville have embeder i Slesvig eller Holsten, skulle have studeret to år ved Kiels universitet. ${ }^{25}$ Denne forordning - det såkaldte kielske "Biennium" resulterede hurtigt $i$, at den slesvigske embedsstand blev mere tysk end dansk orienteret.

Yderligere til gavn for Kiels universitet - men ikke med specielt henblik herpå - var indførelsen af Indfodsretsloven i 1776, hvori det blev fastslået, at adgang til embeder i det danske monarki var forbeholdt indfødte undersåtter eller dermed ligeberettigede. ${ }^{26}$

\section{Medicinaladministrationen}

Tyske Kancelli i København var i henseende til kirke-, undervisnings-, retsog medicinalvæsen øverste administrative myndighed for hertugdømmerne. Det benævntes i perioden 1806-16 Slesvig-Holstenske Kancelli og fra 1816 Slesvig-Holsten-Lauenburgske Kancelli. Øvrighedssproget var tysk. Lokalt udsendtes lovdekreter for de kongelige dele gennem Regeringskancelliet $i$ Glückstadt og for de gottorpske dele af hertugerne på Gottorp. Efter 1721 blev lokal lovgivning udstedt af Overretten på Gottorp, og de enkelte byers magistrater kunne udstede direktiver til regulering af de lokale medicinalforhold.

1732 lod hertug Carl Friedrich af Gottorp oprette et Collegium Medicum $i$ $\mathrm{Kiel}$, der skulle fungere som et lokalt, overordnet administrationsorgan for sundhedsvæsenet. ${ }^{28} \mathrm{Et}$ tilsvarende oprettedes i 1740 i Kebenhavn for Danmark. $^{29}$

I 1804 udstedte kong Christian VII (1766-1808) et patent om oprettelse af et Sanitetskollegium i Kiel (til afløsning af Collegium Medicum), der skulle virke »til Forbedring af Medicinalpolitiet i Vore Hertugdømmer Slesvig og Holsten, Herskabet Pinneberg, Grevskabet Rantzau og Staden Altona «. ${ }^{30}$ En tilsvarende administration - benæunt Sundhedskollegiet - var oprettet i København i $1803 .{ }^{31}$ Sanitetskollegiet i Kiel havde Tyske Kancelli i København som ressortministerium, mens Sundhedskollegiet - for det øvrige Danmark henhørte under Danske Kancelli.

I 1809 blev det foreskrevet, at tildeling af licentiat- eller doktorgrad ved Kiels universitet skulle konfirmeres af Tyske Kancelli. ${ }^{32}$ Denne forordning blev dog atter ophævet i 1817, hvorved også udenlands uddannede læger lettere kunne få tilladelse til at virke i hertugdømmerne. ${ }^{33}$ I 1811 blev det bestemt, at blandt ligeværdige ansøgere til lægestillinger i hertugdømmerne skulle den 
foretrækkes, som også beherskede det danske sprog. ${ }^{34}$ I 1835 bestemtes det, at læger ikke mere skulle aflægge ed til det lokale bystyre, hvor de ville praktisere, men i stedet foretage edsaflæggelsen over for det medicinske fakultet ved Kiels universitet. ${ }^{35}$

Ved opstanden i marts 1848 ophævedes Sanitetskollegiet, men ved oprettelse af en Bestyrelseskommission for Hertugdømmet Slesvig 25. august 1849 genetableredes en medicinaladministration. ${ }^{36}$ Ved Treårskrigens afslutning erstattedes bestyrelseskommissionen den 13. juli 1850 af en Overordentlig Regeringskommission, ${ }^{37}$ men allerede 5 . marts 1851 blev denne nedlagt og dens beføjelser henlagt til det i København nyoprettede Ministerium for Slesvig. ${ }^{38} 1$. Departement i dette ministerium var lige til krigen i 1864 højeste medicinaladministration for hertugdømmet Slesvig, mens den øverste administration på lokalt plan ved forordning af 19. december 1852 blev henlagt til det Kongelige Slesvigske Sanitetskollegium, der etableredes i Flensborg. ${ }^{39}$

Som lokale medicinaladministratorer under først Sanitetskollegiet for Slesvig-Holsten og siden under det Kongelige Slesvigske Sanitetskollegium virkede fysici rundt om i deres distrikter (=fysikater). Om disse findes der oplysninger spredt $\mathrm{i}$ lovgivningen ${ }^{40}$ samt $\mathrm{i}$ »Königlicher Dänischer Hof- und Staats-Kalender « (=hof- og statskalenderen), som begyndte at udkomme i $1734 .{ }^{41}$.

\section{Embedslægeopgaver}

Et reglement fra 1775 for fysikus i Altona beskriver målsætningen for embedslægevæsenet $\mathrm{i}$ hertugdømmerne: varetage statens interesser, udvise troskab mod syge, forestå undersøgelser og iværksætte foranstaltninger ved epidemiske sygdomme samt foretage retsmedicinske undersøgelser efter anmodning fra ovrigheden. ${ }^{42}$

Tilsyn med medicinalpersoner. Ifølge medicinalforordningen fra 1672 skulle fysici eksaminere jordemødre, og ved reskriptet af 1746 blev det udvidet til, at fysici også skulle undervise jordemødrene. ${ }^{43}$ I 1765 oprettedes statslige jordemoderskoler i Flensborg og Altona, hvorefter denne undervisningspligt atter bortfaldt, men pligten til at føre tilsyn med jordemødrenes virke bevaredes. ${ }^{44}$

Også tilsyn med apotekervæsenet var foreskrevet i 1672 -forordningen.$^{45}$ Der skulle foretages visitats på hvert apotek to gange årligt, og i forbindelse med oprettelsen af Sanitetskollegiet i 1804 bestemtes det, at ingen måtte virke som provisor, før han havde bestået en prøve for fysikus og en apoteker. I 1823 indskærpedes, at fysikus skulle foretage apoteksvisitats én gang årligt på 
uvarslede tidspunkter, og der skulle indsendes en visitatsberetning til Sanitetskollegiet. ${ }^{46}$

Læger skulle - som tidligere nævnt - fremstille sig for den lokale fysikus, før der kunne opnås tilladelse til at virke som praktiserende læge, og fysikus skulle fra 1804 føre tilsyn med lægers og kirurgers virksomhed ${ }^{47}$ Kirurgerne var oprindelig udgået fra barberhåndværket, efterhånden fik de en egentlig uddannelse på Kirurgisk Akademi i København, men de måtte kun foretage operationer og således ikke behandle medicinske sygdomme med medikamenter.

Epidemiske sygdomme. Ifølge medicinalforordningen fra 1672 blev det foreskrevet, at ved grasserende pest eller andre smitsomme sygdomme skulle medici på apotekerne "specificere Kure og Medikamenter, så at Enhver kan være tjent dermed « ${ }^{48}$ I reskriptet fra 1746 blev fastslået, at fysikus skulle rådspørges $\mathrm{i}$ tilfælde af smitsomme sygdomme, og han skulle »drage den nødvendige Omsorg « ${ }^{49}$ Bemærkelsesværdigt er det, at fysikus ikke havde pligt til selv at forestå behandlingen, men kunne lade denne ske ved hjælp af andre læger eller kirurger. Ved sanitetskollegiets oprettelse i 1804 bestemtes, at når en læge - altså også en fysikus - fik kendskab til smitsom sygdom, skulle det straks anmeldes til sanitetskollegiet med udførlig beskrivelse af tilfældet, den formodede årsag til sygdommen, samt om det kunne forventes, at den ville brede sig. Hvis sanitetskollegiet derpå fandt det nødvendigt, skulle det $\mathrm{i}$ samarbejde med fysici træffe foranstaltninger mod videre udbredelse. ${ }^{50}$

Indberetninger. Sådanne er også omtalt i medicinalforordningen fra 1672. Heri var foreskrevet, at medici wårligt eller ved forekommende Lejligheder af sjældne og særlige Tilfælde « skal indberette denne til Decanen ved det medicinske fakultet i København. ${ }^{51}$ Om sanitetskollegiet blev besluttet, at medicinalpersoner (læger, sårlæger (kirurger), apotekere og jordemødre) skulle indsende beretning én gang årligt. Endvidere var alle fysici og distriktskirurger forpligtet til at udfærdige de af sanitetskollegiet forlangte indberetninger og følge sanitetskollegiets instrukser. ${ }^{52}$ Sammen med sanitetskollegiets tilforordnede (= adjunkter) skulle fysici indberette om den almindelige sundhedstilstand såvel i egne som i tilgrænsende distrikter, og såvel hvad de selv havde oplevet, som hvad de havde erfaret. ${ }^{53}$

I 1806 blev disse pligtige indberetninger yderligere skærpet. ${ }^{54}$ Disse skulle foretages halvårligt og udfærdiges efter en bestemt plan, og hensigten med indberetningerne var bevarelse og forbedring af den offentlige sundhedstilstand i hertugdømmerne. Der skulle indberettes i "mindste Detalje« om indtrufne begivenheder, beretninger om foretagne undersøgelser af lig, ændringer i medicinalpersonalet, hvilke lokalundersøgelser, besigtigelser, obduktioner, 
apoteksvisitatser, ulykker, selvmord og andre dødsfald, der måtte give anledning til særlig interesse. Desuden skulle indberetningerne omfatte oplysning om luftens beskaffenhed, vejret, næringsmidler og hvad andet, der kunne have betydning for den hyppigste sygelighed. Endelig skulle der indberettes om misbrug og uorden af enhver art, som var uheldig for den offentlige sundhed. Fysikus skulle arkivere en kopi af sin indberetning.

I 1808 foreskrev en kancelliskrivelse, at der i epidemitider skulle indsendes ugentlige indberetninger til sanitetskollegiet, ${ }^{55}$ og i 1816 beordredes en årlig indberetning om koppevaccinationer. ${ }^{56}$ Denne vaccination var ved lov blevet indført i Danmark i 1810 og i hertugdømmerne i $1811 .{ }^{57}$

Retsmedicin. Retslægelige undersøgelser har altid været væsentlige embedslægelige opgaver. Disse bestod i undersøgelse af levende eller døde personer på begæring af en dommer. Derved skulle det afklares, om der kunne være begået en strafbar handling. Det kunne dreje sig om personer, der havde været i slagsmål, om eventuelle seksualforbrydelser eller drab.

I 1776 udstedte overkriminalretten på Gottorp slot en udførlig forskrift for ligsyn og obduktioner til brug for stads- og landfysici. ${ }^{58}$ Der blev heri giort opmærksom på, at det drejer sig om en retslig funktion, og at der kræves særlig opmærksomhed og omhu, da konklusionen kan føre til en retssag. Derpå blev der givet en nøje beskrivelse af, hvad der skulle iagttages ved den ydre undersøgelse af et lig og ved obduktionen af dette.

I 1828 udsendtes en cirkulæreskrivelse om undersøgelse af personer, der var døde som følge af vold. ${ }^{59}$ Det indskærpedes over for rets- og politimyndighederne, at fysikus skulle tilkaldes og holde ligsyn i tilfælde af selvmord, dødsfald i forbindelse med ulykker og andre tilfælde af voldsom død.

Fysikusembedet. Fysici var således praktiserende læger, som af offentlige myndigheder var ansat til at varetage de før nævnte specielle pligter, som andre læger ikke havde. Fysici var, som danske embedslæger stadigvæk er, udnævnt af kongen. I forbindelse med oprettelsen af sanitetskollegiet i 1804 blev det bestemt, at for at kunne blive fysikus skulle der aflægges en prøve for sanitetskollegiet, som også foretog indstilling ved besættelse af ledige fysikater.

I 1816 fastslog et cirkulære, at »de samtlige Herrer Physici« har pligt til, når de ud fra særlige bevæggrunde må foretage nødvendige rejser $\mathrm{i}$ mere end 5-6 dage, at ansøge Sanitetskollegiet om tilladelse til ansættelse af vikar i den offentlige stilling. ${ }^{60}$

Om tavshedspligt foreskrives der intet specielt for fysici eller andre læger $\mathrm{i}$ den ældre medicinallovgivning, men for apotekere, deres svende og medhjælpere fastslår medicinalforordningen af 1672, at disse har tavshedspligt med, hvad patienterne åbenbarer over for dem, og hvad de må have fået kendskab til ud 
fra recepter. ${ }^{61}$ - Man må formode, at andre medicinalpersoner også må have været underkastet tilsvarende tavshedspligt.

Sanitetskollegiet havde visse straffemuligheder over for medicinalpersoner, som overtrådte medicinallovgivningen. Disse sanktioner kunne være tilrettevisning eller fortabelse af retten til at bestride sin stilling. ${ }^{62}$

Over for jordemødre havde fysici en selvstændig kompetence til at foretage straffeforanstaltninger. Dette kunne ske i form af irettesættelse, bøder eller endog kortvarig fangselsstraf. ${ }^{63}$

\section{Embedslægernes økonomiske forhold}

Fysici i hertugdømmerne fik fra bykasserne og amterne en mindre, fast gage specielt som vederlag for at yde gratis lægehjælp til mindrebemidlede. Økonomisk bedrestillede patienter måtte selv aflønne fysikus, såfremt de benyttede ham som praktiserende læge. Men herudover blev fysikus aflønnet for mange af de enkeltydelser, som han foretog, bl.a. retsmedicinske undersøgelser og apoteksvisitatser, og desuden fik han kørselsgodtgørelse og diæter. Afstandene i de fleste fysikatsdistrikter var store, hvorfor fysikus meget vel kunne være borte fra sin bopæl $\mathrm{i}$ embeds medfør $\mathrm{i}$ mange timer, måske flere dage. Transporten fandt sted $\mathrm{i}$ hestevogn eller på hesteryg.

Det

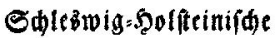

Redicinalverfaffand

in eince

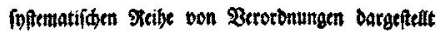

ano

mit sinet fritifden einteitung betfegten

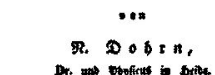

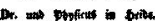

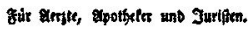

I dansk tid blev der udgivet tre medicinallovsamlinger: 1824 af Flensborg-lagen Thomas Otto Forchhammer, 1834 af $\mathrm{Ni}$ colaus Dohrn, fysikus i Heide og i 1854 af juristen Friedrich Wilhelm Langenheim

pelpe 1834 
I Christian V's medicinalforordning fra 1672 var der i $\$ 10$ en egentlig takstliste, som hidrørte fra Christian IV's forordning fra 1619. Der var fastsat takster for, hvor meget læger, og dermed også fysici, måtte tage $\mathrm{i}$ honorar for konsultation, sygebesøg og receptudstedelse.

Mange gange $\mathrm{i}$ årenes løb blev der $\mathrm{i}$ lovgivningen foreskrevet takster for de ydelser, som fysici fik særligt honorar for. Således omhandler et dekret fra 1733 biindtægter for land- og stadsfysici. ${ }^{65}$ I 1735 foreskrev en deklaration størrelsen af diæter vedrørende fri transport og fornøjeligheder (dvs. andre udgifter) ${ }^{66} 1741$ forelå et reglement for obduktionsgebyrer til fysici, ${ }^{67}$ og i 1742 udstedtes et reskript, efter hvilket fysikus på Femern ikke mere skulle have særskilt honorar for at foretage obduktioner, men i stedet have fri kørsel og to rigsdaler i diæter. ${ }^{68}$

I 1757 udstedtes et større reskript angående fysikatsvæsenet. Heri bestemtes, at fysikus skulle honoreres med 5 skilling for hver enkelt ydelse. Men herudover skulle fysikus også honoreres af den købstad, hvori han havde bopælspligt, det blev derfor indskærpet købstædernes magistrater at budgettere med denne udgift. ${ }^{69}$ I 1792 blev det bestemt, at fysici i amterne og landskaberne i Slesvig og Holsten foruden den vedtægtsmæssige løn og den hidtidige fri kørsel

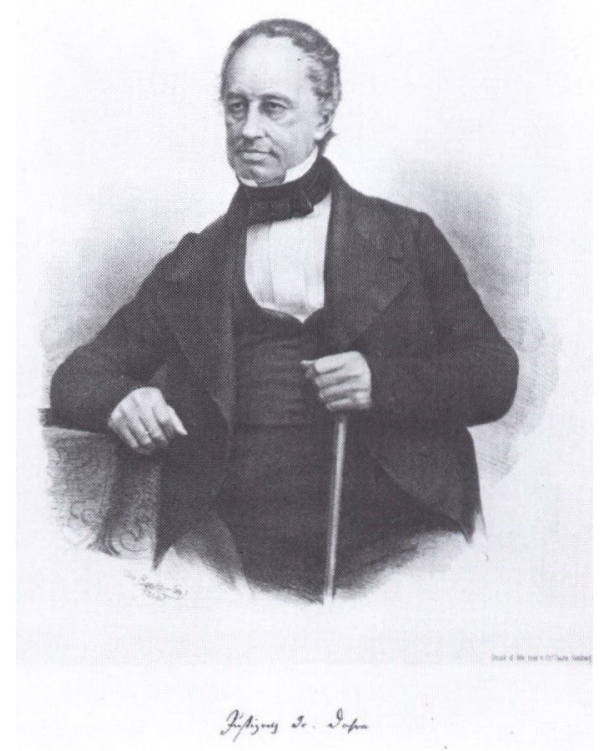

Nicolaus Dohrn, fodt 24.3.1789 i Beienfleth. Steinburg amt, død $i$ Heide 7.2.1858. Han var fysikus $i$ Nordre Ditmarsken med bopal $i$ Heide 1817-58. Det kongelige Bibliotek, Kobenhavn. 
også skulle have en rigsdaler i diæter, når de rejste fra deres bopæl til en anden købstad for dér at foretage obduktion, apoteksvisitats eller undersøge for epidemisk sygdom. ${ }^{70}$

I 1820-erne blev der flere gange udstedt bestemmelser om gebyrer for fysikatsforretninger. ${ }^{71}$ Alligevel fremgår det af polemiske skriverier $i$ datidens kulturelle tidsskrifter, at fysici var utilfredse med deres aflønning. ${ }^{72}$ De måtte sammenstykke deres indtægter af talrige enkeltydelser, og deres faste, offentlige aflønning var kun en ringe del af de samlede indtægter.

Fysicus Nicolaus Dohrn (1789-1858) udgav i 1834 en medicinallovsamling. I forordet til denne skrev han bl.a.: "Man kan i sandhed sige, at til intet erhverv stilles der så store fordringer som til det lægelige, det er forbundet med så store anstrengelser og opofrelser, så megen ubehagelighed og fortrædelighed, ja endog med så megen livsfare. Med stor sandhed kan man derfor nævne, at ingen stand yder staten så mange tjenester som den lægelige«. Dohrn spørger: »Hvad yder staten til gengæld? Høj aflønning? Slet ikke«, svarer Dohrn selv, „den måde, staten aflønner lægerne på, kan sammenlignes med en aflønning af en daglejer, men det vil lægerne ikke affinde sig med «! ${ }^{73}$

Alle læger var dog ikke lige utilfredse med deres aflønning. Således blev fysikus Dohrn imødegået af sin kollega Gustav Adolf Michaelis (1798-1848), der 1835-41 var fysikus $\mathrm{i}$ Kiel by og de holstenske amter Cronshagen og Bordesholm og derpå til sin død var professor i fødselshjælp ved Kiels universitet. Michaelis skrev, at erfaringen viste, at lægetaksterne var så høje, at kun de rige kunne betale, og at $9 / 10$ af befolkningen ikke var i stand til at betale disse honorarer uden at blive ruinerede. ${ }^{74}$

Også dengang var læger altså stærkt optaget af deres egne indtægter.

\section{Lovgivning om fysikatsdistrikterne}

De landområder, som udgjorde fysikatsdistrikterne var af meget varieret størrelse. Afstandene var derfor ofte store, vejene dårlige, og specielt kunne trafikforholdene til øerne i vadehavet være vanskelige.

Straks efter sanitetskollegiets oprettelse i 1804 blev det pålagt at foretage en ændring af fysikatsdistrikterne, således at disse blev af mere ensartet størrelse og bedre arronderede. ${ }^{75}$

Yderligere skulle sanitetskollegiet finde en løsning på den embedslægelige dækning af godsdistrikterne, som udgjorde store områder i den østlige del af hertugdømmet Slesvig (Svans, Dänischwohld og dele af Angel), men som især udgjorde en meget stor del af Holsten. Livegenskabet blev ophævet i 1805, og herved bortfaldt de forpligtelser, som godsejerne havde til at sikre læge- og 
jordemoderbistand til deres undergivne. ${ }^{76}$ I forvejen hørte godsdistrikterne ikke ind under fysikaterne.

Medens sanitetskollegiet arbejdede med disse problemer - hvilket det gjorde lige indtil 1848, uden at problemerne blev løst - blev samtlige fysici ansat med stillingsbetegnelsen interimsfysici, dvs. midlertidigt ansat $\mathrm{i}$ det pågældende fysikat.

Der foreligger kun i ringe grad lovgivning om oprettelse af de enkelte fysikater. Et øvrighedsdekret fra 1749 foreskrev, at stads- og landfysikus i Flensborg også skulle fungere som stads- og landfysikus i Slesvig by og amt. ${ }^{77}$

19. august 1757 udstedte kong Frederik V (1746-1766) på Fredensborg Slot et reskript til statholderen angående en opdeling af hertugdømmerne i Slesvig og Holsten i fysikatsdistrikter ${ }^{.78}$

1. Haderslev by og amt,

2. Flensborg by og amt, landskabet Bredsted og stiftsfogderiet Bordelum,

3. amterne Sønderborg og Nordborg, desuden Gråsten, Søbygård og Gudsgave (alle tre godser på Ærø), samt byerne Sønderborg og Ærøskøbing,

4. Aabenraa og Løgumkloster amter samt byen Aabenraa,

5. Slesvig by, amterne Gottorp og Maarkær samt landskabet Stapelholm,

6. Ekernførde by og Hytten amt,

7. Husum amt, fogderierne Svabsted og Rødenæs, byerne Husum og Frederiksstad samt landskabet Nordstand foruden Pelvorm og Halligerne,

8. Rendsborg by og amt,

9. Segeberg by og amt samt byen Oldesloe,

10. Krempe- og Wilster-marsk, byerne Itzehoe, Krempe, Wilster og Glückstadt.

Det blev foreskrevet, at i hvert distrikt skulle der være en distriktsfysikus. De første syv distrikter var beliggende $\mathrm{i}$ hertugdømmet Slesvig, mens de tre sidstnævnte lå i Holsten. I en eftersætning blev der gjort opmærksom på, at Tønder fysikatsdistrikt blev bibeholdt. Eidersted og Femern var ikke omtalt, der skete imidlertid ingen ændringer ved disse landskabers fysikater. Der var således nu ialt 10 fysikatsdistrikter $\mathrm{i}$ hertugdømmet Slesvig.

"Ad autonomiens og sædvanens vej« havde Eidersted gennem århundreder udviklet den største selvstændighed og frihed blandt alle distrikter $i$ hertugdømmet. ${ }^{79}$ Ved reskript af 9 . december 1750 var landskabets ret til selv at vælge fysikus blevet fastslået, ${ }^{80}$ og dette skete ved hvert tronskifte. ${ }^{81}$

Eidersted, Femern, Stapelholm, øen Nordstrand og øen Sild (undtagen nordligste del, der var kongerigsk enklave) samt Ditmarsken betegnedes landskaber. Disse var administrative enheder, som på mange måder lignede amterne, men havde fra gammel tid et betydeligt større selvstyre end disse. 


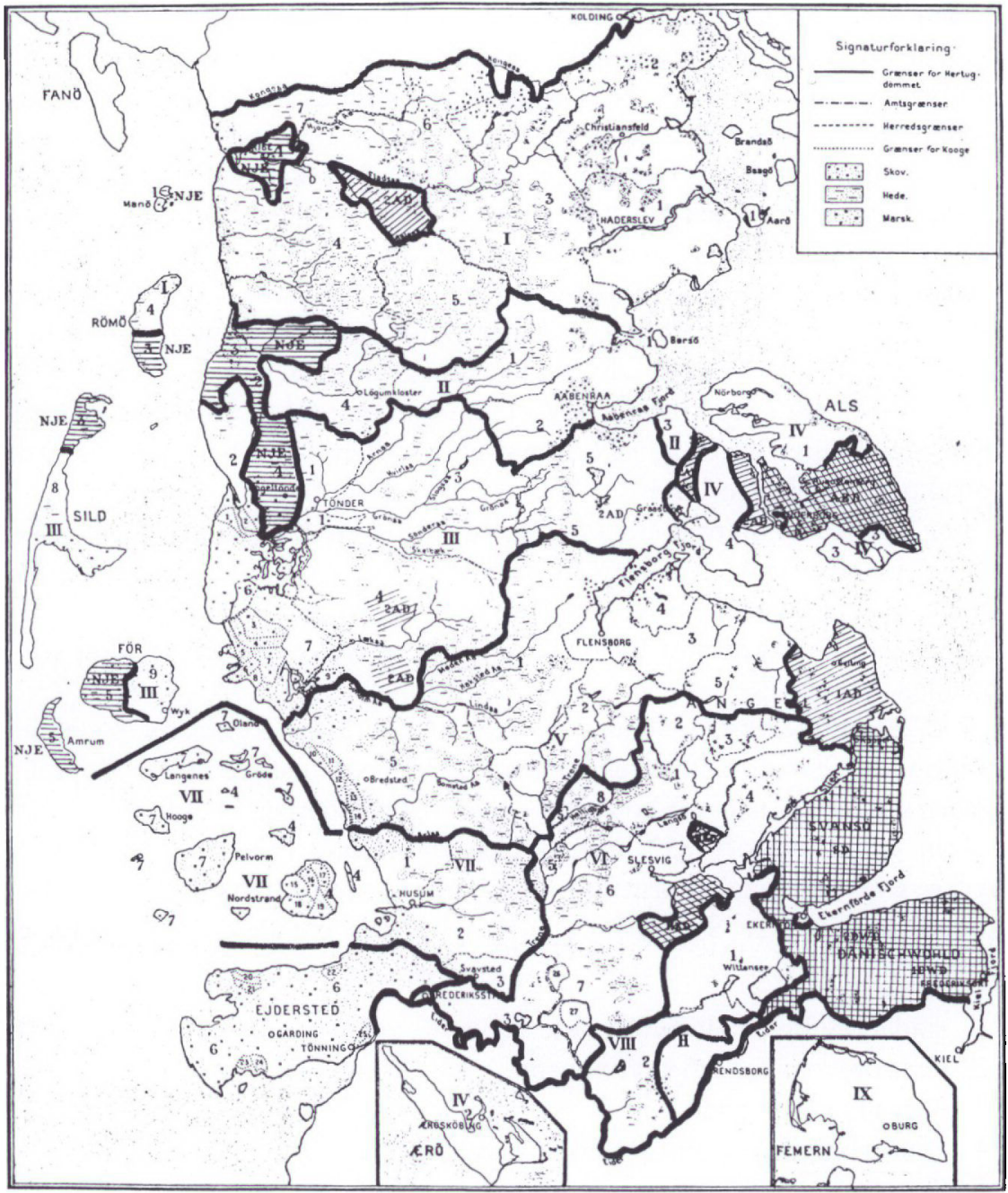

De 10 fysikater efter 1757. Nummerering med romertal svarer til 1804-numrene pd figuren side 207. Vandret skravering $=$ kongerigske enklaver, skrå skravering = Augustenborg og Sct. Hans kloster $i$ Slesvig by, kryds skravering $=$ Svanso og Dänischwohld (Jernved) godsdistrikter.

Når man kunne »nøjes« med kun tre fysikatsdistrikter i Holsten skyldtes det, at meget store dele af dette hertugdømme bestod af store adelige godser, der som næunt ikke var underlagt noget fysikatsdistrikt, samt at Altona, Herskabet Pinneberg, Grevskabet Rantzau og Ditmarsken, der ikke hørte til det egentlige Holsten, var "glemt« ligesom Eidersted og Femern. 
Reskriptet fra 1757 bevirkede, at det meste af hertugdømmet Slesvig var dækket ind med fysici. Men distrikterne var stadig af meget forskellig størrelse, og spredt $i$ disse lå godsdistrikter og gejstlige områder, der ikke var underlagt fysikus. Disse forhold blev kun langsomt ændret, og først i 1852 kan man sige, at forholdene var blevet tilfredsstillende. Det kan nævnes, at ved et reskript af 1781 blev det Glücksborg-Angelske $=1$. Anglerdistrikt tillagt fysikus i Flensborg, ${ }^{82}$ og det Glücksborg-Sundevedske $=$ en del af 2 . Anglerdistrikt henlagt til Sønderborg fysikatsdistrikt. ${ }^{83}$ På grund af vanskelige trafikale forhold oprettedes 1785 et landkirurgdistrikt for øen Sild underlagt fysikus i Tønder. ${ }^{84} 1786$ blev ÆErø et selvstændigt fysikatsdistrikt. ${ }^{85}$

En forordning i 1787 påbød, at de i amterne Haderslev, Tønder, Aabenraa og Løgumkloster varende adelige godsundersåtter skulle henhøre under de respektive fysikatsdistrikter. ${ }^{86}$

For landskabet Stapelholm ansattes der i 1810 en distriktslæge med bopæl i Sønder Stapel under fysikus i Ekernførde, ${ }^{87}$ og i 1816 blev der oprettet en stilling som landkirurg på øen Nordstrand under fysikus i Husum..$^{88}$

1822 blev Bredsted amt frastykket Flensborg fysikatsdistrikt som et selvstændigt embede. ${ }^{89}$

I 1823 oprettedes en stilling som distriktskirurg for Rømø for både den nordlige del, hørende til hertugdømmet og dermed underlagt Tyske Kancelli, og den sydlige del, som var kongerigsk enklave og underlagt Danske Kancelli. ${ }^{90}$

Den 19. december 1852 udstedtes en forordning dels om oprettelse af særlige over-medicinalautoriteter i Flensborg for hertugdømmet Slesvig - Det kongelige slesvigske Sanitetskollegium - og dels om dette hertugdømmes nyinddeling $i 17$ fysikatsdistrikter: ${ }^{91}$

1. Haderslev by og Haderslev øster-amt,

2. Gram by og Haderslev vester-amt,

3. Aabenraa by og amt,

4. Sønderborg by og amt, Nordborg og Gråsten,

5. Ærø,

6. Tønder by samt Tønder- og Løgumkloster amter,

7. Niebøl og Syd-Tønder amt,

8. Flensborg stadsfysikatsdistrikt,

9. Flensborg landfysikatsdistrikt,

10. Kappel med sydlige del af Angel,

11. Ekernførde og Hytten amter,

12. Slesvig by og amt,

13. Bredsted amt,

14. Husum amt,

15. Tønning by og landskabet Eidersted, 
16. Sønderstapel landdistrikt og Frederiksstad by,

17. Femern med byen Burg.

Denne omorganisering af medicinalvæsenet i Slesvig var et naturligt led i de administrative ændringer, der fandt sted efter Treårskrigen 1848-50. En tilsvarende ændring af medicinalvæsenet fandt også sted i Holsten. ${ }^{92}$

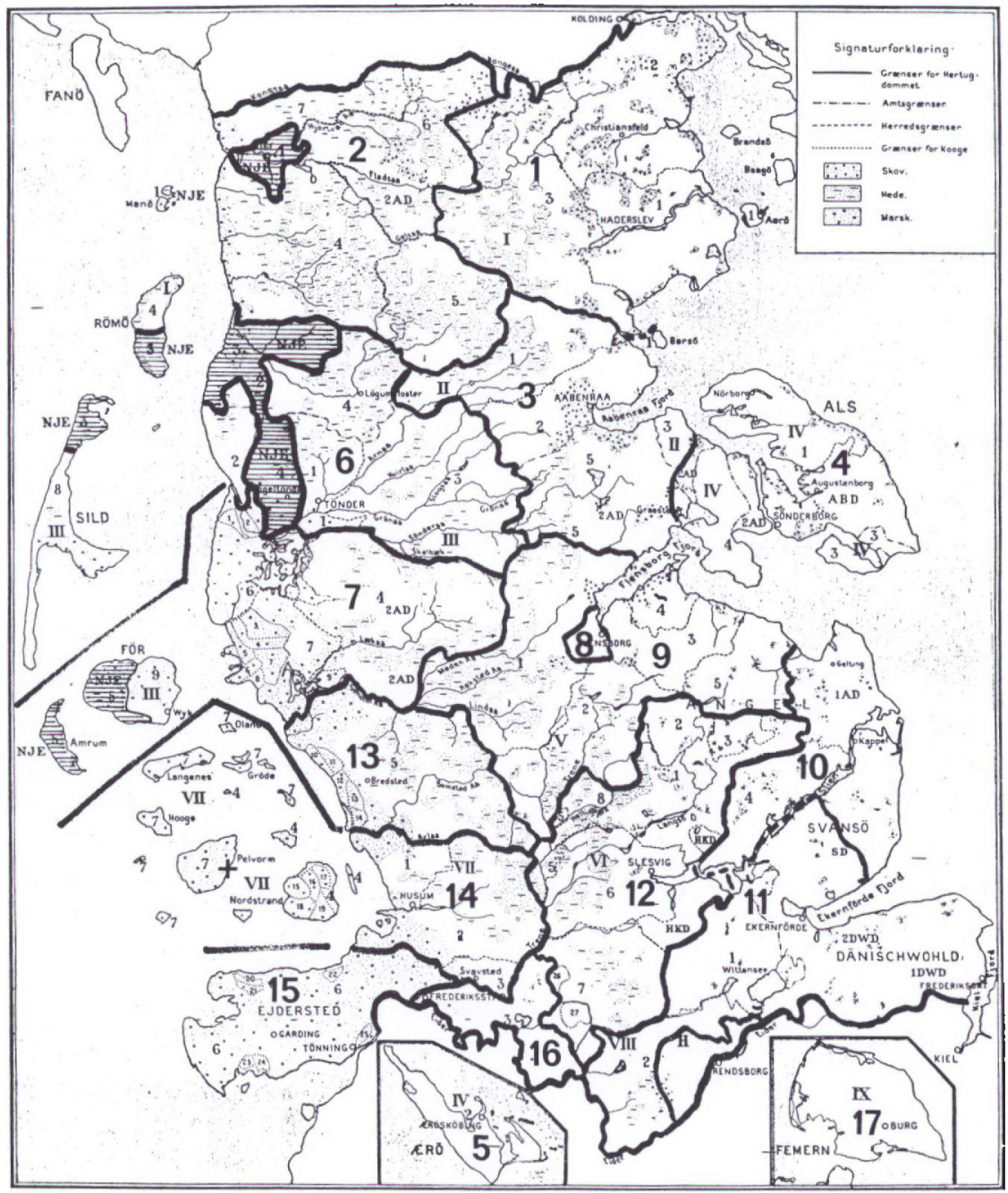

De 17 fysikater $i 1864$ nummereret med fede arabertal svarer til 1852-nummereringen pá figuren side 207. Vandret skravering = kongerigske enklaver dvs. Ribe sondre lagedistrikt. 
I en ministeriel skrivelse fra 1857 blev det beordret, at afsondrede bestanddele af et jurisdiktionsdistrikt, der ligger inden for et andet fysikatsdistrikt end det, hvortil jurisdiktionsdistriktet henhører, skal henhøre til det fysikatsdistrikt, i hvilket det er beliggende..$^{93}$ Dette viser med tydelighed, at den administrative arrondering og rationalisering var vanskelig at gennemføre og tog mange år.

Ved en resolution i 1859 oprettedes et særskilt lægedistrikt af Lø Herred, Møgeltønder og Ballum birker samt Vesterland på Før og Amrum - altså de tidligere nævnte kongerigske enklaver. ${ }^{94}$ Det benæuntes Ribe sondre lagedistrikt, og var underlagt fysikus i Ribe. Distriktslægen fik bopæl i Højer. Embedet blev nedlagt i 1867 .

\section{De enkelte fysikater}

Ifølge reskriptet fra 1757 skulle der være 10 fysikater i hertugdømmet Slesvig, men oprettelsen af alle disse nye embeder synes ikke at have fundet sted straks. Fra 1786 var der 11 fysikatsdistrikter (+ Ærø), fra 1822 var der $12(+$ Bredsted), og ifølge forordningen fra 1852 skulle der være 17 - endda nummererede - fysikater i Slesvig. I 1854 var alle embeder blevet besat.

Man kan stille spørgsmålene: opstod alle disse fysikater ud fra deling af ét stort fysikat omfattende hele hertugdømmet Slesvig - og endda måske også omfattende Holsten? - eller opstod de mere eller mindre »tilfældigt« rundt om i landsdelen?

Omkring 1685 omtales en land- og stadsfysikus i Tønning (Eidersted). ${ }^{15}$ Den flittige historiker Th.O. Achelis skriver: „Omkring 1685 bliver en land- og stadsfysikus nævnt, det drejer sig om en landfysikus i Flensborg«. Videre oplyser Achelis: "Endnu 1727 hedder det i bestallingen for Johan Jacob Vogel som landfysikus i hertugdømmet Holsten og stadsfysikus i Itzehoe, at hertugdømmet Slesvig ikke hidtil har været forsynet med en sådan Subjecto«. Barthold Wichers (*?, død 1732), der var fysikus i Flensborg 1711-1732, fik bestalling omkring 1724 til »landphysicus i Vort Hertugdømme Slesvig, således også til Physico i de slesvigske Byer og Amter, dog undtagen begge Byer og Amter Haderslev og Tønder, der allerede er nomineret og forordnet med Stads- og Landphysici«. ${ }^{95}$ (Eidersted og Femern var ikke nævnt). Wichers' efterfølger Georg Daniel Bossel (1704-1785), der var fysikus 1732-1785, fik et tilsvarende bestallingsbrev. ${ }^{96}$

Man må dog ikke umiddelbart deraf forledes til at tro, at hele hertugdømmet fra midten af 1720-erne var opdelt i fysikater. I 1749 dekreteredes, at stadsog landfysikus i Flensborg også skulle virke som stads- og landfysikus i Slesvig 
Titelblad fra Hof- und Staats-Kalender 1734. Hof- og Statskalenderen begyndte at udkomme i 1734. Den var skrevet pd tysk, selv om den indeholdt oplysninger om hele det danske monarki. Forst i 1801 udkom den også pd dansk. Med kun meget få undtagelser er Hof-og Statskalenderen udkommet hvert dr - og gor det stadig.

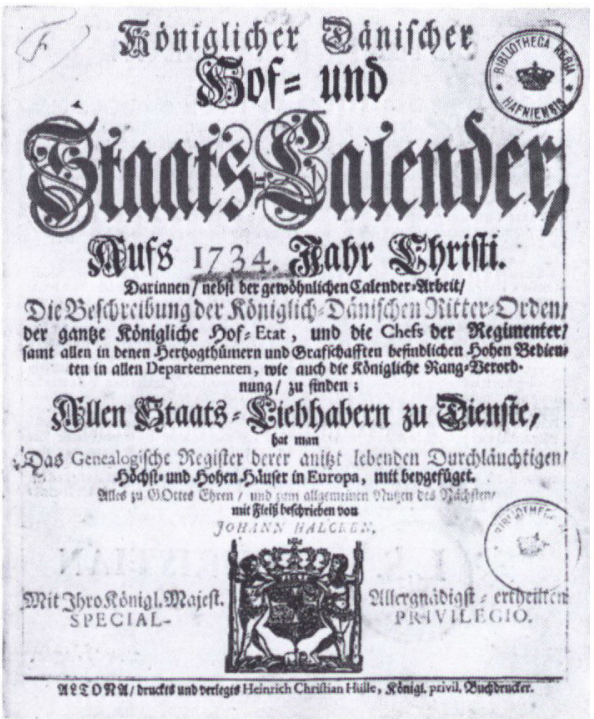

by og amt. ${ }^{97}$ Dette dekret kan tænkes at være udsprunget af det tidligere omtalte reskript af 15 . august 1746, der faktisk først blev udformet i 1749 .

Det må således konkluderes, at der ikke på noget tidspunkt har været én fysikus for hele hertugdømmet Slesvig. Men det er ret sandsynligt, at fysikatet i Flensborg fra 1749 til 1757 omfattede hele hertugdømmet undtagen Haderslev by og amt, Tønder by og amt, Eidersted og Femern.

I det følgende gives en kort beskrivelse af hver af de 17 fysikater.

\section{Flensborg fysikatsdistrikt}

I perioden 1603-1675 kendes 6 stadsfysici i Flensborg, men fra 1676 til 1696 findes der ingen oplysninger om, hvem der var fysikus i byen - og fra 1685 også i landdistriktet. Fra 1696 til 1724 havde Flensborg og Haderslev fælles fysikus (bortset fra en del af året 1711), og fysikus var bosiddende i Flensborg. ${ }^{98}$ Det vil derfor vare en nærliggende tanke, at fysikus Hermann Grube (16371698) fra 1676 til 1696 bestred både Flensborg og Haderslev fysikater med bopæl i Haderslev. Han havde fra 1675 til 1676 været læge i Flensborg, men flyttede derpå til Haderslev, hvor han virkede som fysikus fra 1682 til 1696.9

Ved reskriptet i 1757 reduceredes fysikatet i Flensborg ved, at der efterhånden (se senere) oprettedes selvstændige fysikater i Aabenraa, Sønderborg, Slesvig, Ekernførde og Husum. ${ }^{78}$ Fysikatet omfattede derefter Flensborg by og amt, Bredsted amt og Bordelum fogderi. 1781 fik det tillagt 1. Anglerdistrikt og Nybøl gods (i Angel), ${ }^{82}$ men 1822 blev Bredsted amt udskilt som et selvstændigt fysikat. ${ }^{89}$ $1853 / 54$ blev Flensborgfysikatet delt $i$ et landfysikat og et stadsfysikat. ${ }^{91}$

I perioden 1724-1853 kendes en kronologisk rakke af 7 land- og stadsfysici, og $i$ alt kendes navnene på 17 fysici i Flensborg. ${ }^{98}$ 


\section{Haderslev fysikatsdistrikt}

1682 oprettedes et selvstændigt fysikat omfattende Haderslev by og amt ${ }^{100}$ måske med fysikus fælles med Flensborg. Noget tyder på, at fysikus i Haderslev en periode - måske helt fra 1724 - også virkede i Aabenraa, idet der oplyses om August Wilhelm Heilmann (1695-1766), der var fysikus i Haderslev 1724-1742, at han som "Stadsphysicus i Aabenraa i 1732 godkendte praksisret i Aabenraa for en barberkirurg. ${ }^{101}$

1787 blev Gram og Nybøl godser (= en del af 2. Angler-distrikt) lagt ind under fysikus i Haderslev ${ }^{86}$ men 1852 udskiltes hele Haderslev vesteramt inklusive den nordlige del af Rømø som et selvstændigt fysikatsdistrikt (= Gram) ${ }^{91}$

Indtil 1864 kendes navnene på 12 fysici i Haderslev. ${ }^{102}$

\section{Tonder fysikatsdistrikt}

I 1691 oprettedes et fysikat omfattende Tønder by og amt, der hørte under hertugen af Gottorp. ${ }^{103}$ Oprettelse af denne embedslægestilling synes at være hertugens ønske om en forbedring af apotekerog jordemodervæsenet ved øget tilsyn og undervisning. Det er tænkeligt, at medicinalordningen fra 1672 har inspireret dertil. Tønder var på daværende tidspunkt et »kraftcentrum « på Slesvigs vestkyst, og derfor fandtes der behov for en fysikus.

1785 aflastedes fysikus ved ansættelse af en landskabslæge på Sild. ${ }^{84} 1787$ tilførtes fysikatet næsten alle de $\mathrm{i}$ amtet beliggende adelige godser. ${ }^{86}$

Efter afslutningen af krigen 1848-1850 skete der store forandringer i Tønder fysikatsdistrikt. Lundtoft herred flyttedes fra Tønder til Aabenraa amt ${ }^{104}$ og flyttedes dermed også fysikatsmæssigt. Til gengald overførtes Løgumkloster amt fra fysikatet i Aabenraa til Tønder-fysikus. Sydtønder amt frastykkedes som det selvstændige Niebøl fysikatsdistrikt. ${ }^{105}$ Lø herred, der var kongerigsk enklave, kom også under fysikus i Tønder, men allerede 1859 frastykkedes det igen for at indgå i Ribe søndre lægedistrikt, der netop kom til at bestå af enklaverne. ${ }^{94} 1857$ blev de i Tønder amt beliggende godser Søndergårde, Solvig og Store Tønde tillagt Tønder-fysikatet. ${ }^{93}$

Der kendes en ubrudt række på 9 fysici i Tønder. ${ }^{106}$

\section{Femern fysikatsdistrikt}

1703 oprettedes et selvstændigt fysikat for den til hertugdømmet Slesvig hørende ø ved østkysten af Holsten. ${ }^{107}$

Fra 1739 til ca. 1770 var der til fysikatet henlagt et lille holstensk område på fastlandet omkring byerne Heiligenhafen og Lütjenburg. ${ }^{108}$ Ligesom Eidersted havde Femern også det privilegium selv at kunne vælge sin fysikus. Interessant er også, at der synes at have været nær kontakt mellem disse to slesvigske landskaber på henholdsvis østkysten og vestkysten af Slesvig-Holsten. Dette kan erkendes ved specielle slægtsnavne, som fandtes - og stadig findes - på Femern og i Eidersted. ${ }^{109}$

8 fysici har virket på Femern fra 1703 til $1864 .^{110}$

\section{Eidersted fysikatsdistrikt}

Omkring 1685 omtales en land- og stadsfysikus i Tønning, men noget nærmere herom kendes ikke. ${ }^{15}$ Fra 1720 til 1721 virkede Christoph Martin Burchardi (1680-1742) som fysikus i Eidersted. ${ }^{16}$ Derefter synes stillingen ikke at være besat før 1739, men fra da af kendes en kontinuerlig række af 8 fysici indtil $1864 .^{111}$

Jacob Samuel Sieverts (1707-1750) angives at være blevet udnævnt til fysikus i Eidersted i 1739, men han var læge i Tønning fra 1736, så det kan tænkes, at han allerede var fysikus fra dette tidspunkt. ${ }^{112}$

Landskabet Eidersteds frie forfatning og dermed tilladelse til selv at vælge sin fysikus blev bekræftet ved et reskript i 1746 og gentaget ved en statholderskrivelse i 1750. Dog stilledes den betingelse, at kun en dertil kvalificeret læge kunne foreslås som fysikus, og fysikus i Flensborg skulle efterprøve den indstilledes faglige kundskaber, før udnævnelse kunne finde sted. ${ }^{80}$ Denne ret til selv at vælge fysikus blev siden fornyet ved hvert tronskifte. ${ }^{81}$ 


\section{Husum fysikatsdistrikt}

Dette blev oprettet 1757, og embedet blev besat samme år. Fysikatet bestod af Husum by og amt, Frederiksstad, landskabet Nordstrand, øen Pelworm og de øvrige Halliger. ${ }^{78}$

I 1829 blev visse fysikatspligter i byen Frederiksstad overdraget til en der bosiddende læge, ${ }^{113}$ men i 1852 blev denne by indlemmet $i$ det nyoprettede Sønderstapel fysikatsdistrikt. ${ }^{9 t}$

Der kendes en ubrudt rakke på 6 fysici samt én konstitueret fysikus i Husum indtil 1864. ${ }^{1 / 4}$

\section{Aabenraa fysikatsdistrikt}

Reskriptet fra 1757 foranledigede, at dette fysikat blev oprettet og stillingen som fysikus besat $i$ 1759. ${ }^{78}$ Siden har der indtil 1864 virket 9 fysici i Aabenraa. ${ }^{115}$ Fysikatet omfattede oprindelig Aabenraa by og amt samt Løgumkloster amt, men i 1852 blev Løgumkloster amt overført til fysikus i Tønder, medens denne afstod Lundtoft herred til kollegaen i Aabenraa. ${ }^{91}$

\section{Sønderborg fysikatsdistrikt}

Det bestemtes i 1757 , at dette fysikat skulle oprettes, og det omfattede Sønderborg og Nordborg amter samt Ærø. ${ }^{78}$ Men først i 1764 blev embedet besat.

I 1781 fik fysikatet tillagt det Glücksborg-Sundevedske distrikt =en del af 2. Angler-distrikt samt godset Blansgaard i Sundeved, ${ }^{83}$ og i 1786 blev Erø et selvstændigt fysikat. ${ }^{85}$

Ifølge reformen i 1852 kom fysikatet til at bestå af Sønderborg by, hele Als samt Sundeved og Gråsten gods. ${ }^{91}$

En ubrudt rakke af 7 fysici kendes indtil $1864 .^{116}$

\section{Slesvig fysikatsdistrikt}

Dette blev også oprettet ifølge reskriptet fra 1757 og omfattede Slesvig by, amterne Gottorp og Maarkær samt landskabet Stapelholm. ${ }^{78}$

Den første fysikus, der kendes i Slesvig er Joachim Fürsen (1717-1778), som virkede der fra 1768 til 1778. ${ }^{117}$ Måske har den flensborgske fysikus G.D. Bøssel også haft Slesvig fysikat underlagt sig lige fra 1749 til 1768 (se tidligere). ${ }^{77}$ Men Fürsen var læge i Slesvig fra 1754, så det kan tænkes, at han har fungeret som fysikus der fra omkring $1757 .^{118}$

7 fysici og én konstitueret fysikus har virket i Slesvig-fysikatet fra 1768 til $1864 .^{119}$

\section{Ekernforde fysikatsdistrikt}

Dette omfattede Ekernforde by og Hytten amt og var også et af de 5 nyoprettede fysikater, der var foreskrevet i 1757-reskriptet. ${ }^{78}$

Også dér synes der først at være blevet udnæunt en fysikus i 1768. Det var Georg Ferdinand Wegener (ca. 1730-1787), der var fysikus lige indtil sin død, men som havde været læge i Ekernførde fra 1753 og derfor egentlig meget vel kan have virket som fysikus dér fra omkring $1757 .{ }^{120}$

1777 fik fysikatet tillagt Hohn herred og Stapelholm fra Slesvig fysikatsdistrikt. ${ }^{121}$ I 1852 oprettedes et nyt fysikat i Senderstapel, hvortil Hohn herred og Stapelholm da overflyttedes. ${ }^{91}$ Ekernforde fysikatsdistrikt bestod derefter af Ekernforde by og Hytten herred, Dänischwohld og den vestlige del af Svans med de der beliggende godser. Den ostlige del af Svans (halvøen syd for Slien) kom under fysikatet i Kappel.

6 fysici og én konstitueret fysikus har virket i embedet fra 1768 til 1864.122

\section{Aro fysikatsdistrikt}

Denne slesvigske $ø$ hørte fra 1757 under fysikatet i Sønderborg, ${ }^{78}$ men 1786 blev den et selvstæendigt fysikat, ${ }^{85}$ og der fandt ingen andringer sted i 1852 . Ved fredsslutningen i 1864 forblev Ærø ved Danmark, og øen blev i 1867 underlagt Fyns stiftsfysikat forestået af en distriktslæge. ${ }^{123}$

I alt har der varet 4 fysici og én konstitueret fysikus på Erø i perioden 1786-1864. ${ }^{124}$ 


\section{Bredsted fysikatsdistrikt}

Ved en kancelliskrivelse i 1822 blev Bredsted amt frastykket Flensborg fysikatsdistrikt, idet det kom til at udgøre et selvstændigt fysikat. ${ }^{89}$ Dette bestod uændret til 1864 og 4 fysici virkede der i de 42 år. ${ }^{12 s}$

\section{Gram fysikatsdistrikt}

Ved forordning af 1852 blev Haderslev vesteramt med godserne Gram og Nybøl (en del af 2. Anglerdistrikt) frastykket Haderslev fysikatet og blev et selvstændigt fysikatsdistrikt. ${ }^{91}$ I administrativ henseende var fysikatet meget kompliceret, idet det udgjorde en væsentlig del af de såkaldte blandede kongerigske/slesvigske sogne.

Embedet blev forst besat i 1854 og kun én fysikus: Martin Reimers (1812-1876) virkede dér. ${ }^{126}$

\section{Niebol fysikatsdistrikt}

Dette blev også oprettet ifølge forordningen af $1852,{ }^{91}$ og stillingen blev besat i 1853 med Niels Westy Bech (1825-1885), som blev afsat af preusserne i $18644^{127}$ Niebøl (eller Nybøl) fysikatsdistrikt bestod af Sydtender amt, som blev afstået fra Tønder fysikatsdistrikt. Det omfattede således Kær, Viding og Bøking herreder samt østerlandet på Før. Vesterlandet på Før og øen Amrum var kongerigske enklaver, hvorfor disse områder ikke kom under fysikatet i Niebøl, men fra 1859 under Ribe søndre lægedistrikt.

\section{Kappel fysikatsdistrikt}

Med fiækken Kappel som hovedby og den sydøstlige del af Angel samt de østlige godsområder på Svans oprettedes et fysikat ifølge forordningen fra $1852 .{ }^{91}$ Embedet blev besat i 1853 med Asmus Julius Thomas Thomsen (1815-1896), der var den eneste fysikus i Kappel i dansk tid. ${ }^{128}$

\section{Sønderstapel fysikatsdistrikt}

Der oprettedes også et nyt fysikat ifølge 1852-forordningen i Sønderstapel ${ }^{91}$ omfattende denne by og Hohn herred, som blev afstået fra fysikatet i Ekernforde, samt Frederiksstad, der hidtil havde hørt under fysikus i Husum. Endelig kom fysikatet også til at omfatte kancelligodset Neulandshof og Kleinseer Koog. ${ }^{129}$

I 1810 var der dog blevet ansat en distriktslæge i Sønderstapel til aflastning for fysikus i Ekernførde, ${ }^{87}$ og i 1829 var visse embedslægeopgaver i Frederiksstad blevet overdraget en derboende læge for at aflaste fysikus i Husum. ${ }^{113}$

2 fysici nåede at virke i embedet inden 1864: Christian Heinrich August Schreder (*?, død 1865) 1853-1859 og Heinrich August Theodor Schacht (1813, død ?) 1859-1864. ${ }^{130}$

\section{Ribe amts søndre lagedistrikt}

Dette embedslægedistrikt omfattende de kongerigske $=$ nørrejyske enklaver $i$ Vestslesvig oprettedes $i$ $1859,9^{94}$ og distriktslægen Amton Heyn (1828-1913) havde bopæl i Højer. ${ }^{131}$

\section{Fysico-grafi}

I hertugdømmet Slesvig kendes der i perioden fra 1603 til 1864 nøjagtig 100 fastansatte og konstituerede fysici. Ud fra biografier om disse er udarbejdet en lille statistisk undersøgelse af, hvor fysici er født, hvor de har afsluttet deres 


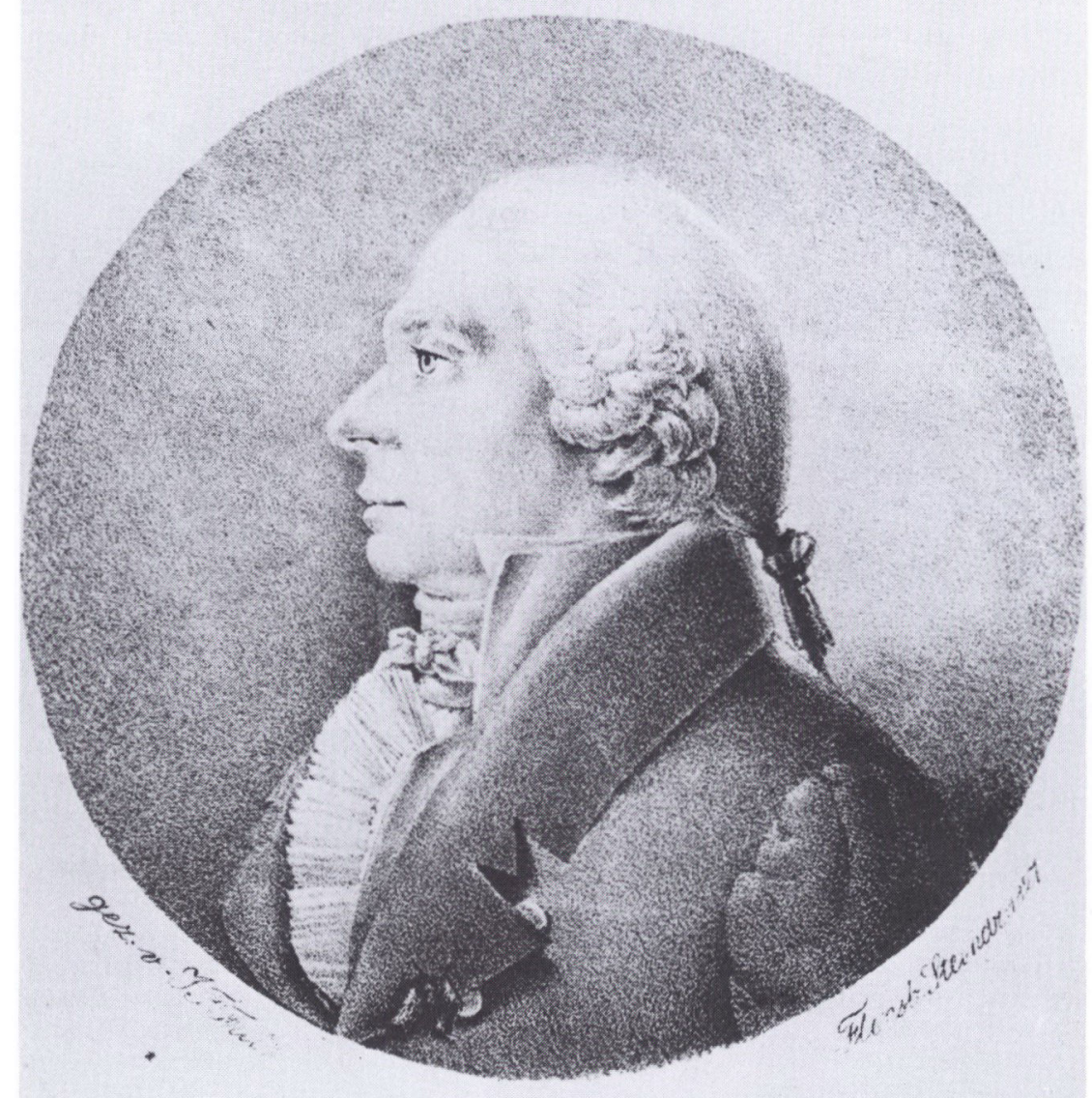

En af de indflydelsesrige embedslager $i$ hertugdommet Slesvig var fysikus Carl Ferdinand Suadicani. Han var fodt den 17.12.1753 i Preetz, hvor faderen var apoteker. Han studerede medicin $i$ Kiel fra 1770 og $i$ Göttingen fra 1772 og blev dr.med. dér $i$ 1774. Straks efter nedsatte Suadicani sig som lage $i$ Preetz, men $i 1778$ flyttede han til Glückstadt. 1782 blev han fysikus $i$ Segeberg (byerne Segeberg og Oldesloe, amterne Segeberg og Traventhal). Imidlertid forlod han dette embede $i 1793$ for at blive livlage for hertugen af Augustenborg. 1795 blev Suadicani kongelig dansk archiater dvs. livlage, og $i$ 1796 ledsagede han kronprinsen, den senere kong Frederik VI pd en baderejse. 1801 blev Suadicani livlage for landgreve Carl af Hessen, som boede pd Gottorp slot, og diret efter blev han fysikus $i$ Slesvig by og Gottorp amt. Suadicanis vasentligste lagelige indsats var oprettelsen af sindssygehuset i Slesvig. En plan herom arbejdede han pd $i$ adskillige dr og takket vare hans gode kontakt til kongen, lykkedes det ham sammen med arkitekten C. F. Hansen $i$ d̊rene 1817-20 at fả bygget et sindssygehospital $i$ byen Slesvig. det forste danske sindssygehus uden for Københavns kommune - og det eksisterer stadig. C.F. Suadicani dode $i$ Slesvig den 22.02.1824. 
universitetsuddannelse, og hvilken social status deres fader havde. Desuden er det registreret, om fysici har skiftet embede, det vil sige virket i én eller flere embedslægestillinger i deres livsforløb. Endelig er det opgjort, hvor mange fysici, der var udnævnt før og efter krigen 1848-50.

Angånde social proveniens er der foretaget en opdeling i højere, middel og lavere social klasse. Under højere social status henregnes akademiker, højere embedsmand, lærer, godsejer og godsforpagter. Til middel social klasse henføres bl.a. gårdejer, købmand, skibsfører, lavere embedsmand og militærkirurg. Ved lavere social status forstås her håndværker, arbejder og mindre landbruger.

\section{Fødested}

Slesvig-Holsten øvrige Danmark

Tyskland

andre lande

ukendt

Social proveniens:

højere

middel

lavere

ukendt

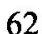

17

16

2

3

52

18

6

24
Eksamenssted:

Kiel

41

København $\quad 18$

Tyskland 21

andre lande 8

ukendt

12

Antal stillinger:

kun én i htd. Slesvig $\quad 78$

flere i htd. Slesvig 3

også i htd. Holsten 9

også i øvr. Danmark 10

Udnavnelsestidspunkt:

$\begin{array}{ll}\text { før } 1848-50 & 78 \\ \text { efter } 1848-50 & 22\end{array}$

Det fremgår af oversigten, at de fleste fysici var født i hertugdømmerne og i Tyskland. Kun 17 fysici var født nord for Kongeåen, og 11 af disse var endda blandt de 22 fysici, der blev udnævnt efter 1850, da der blev ført en egentlig fordanskningspolitik i hertugdømmet Slesvig.

Også flertallet af fysici havde afsluttet deres studier ved universitetet $\mathrm{i}$ Kiel eller i Tyskland. 18 fysici havde afsluttet deres studier ved Københavns universitet, og blandt disse var 11 udnævnt efter 1850.

Endelig kan det ikke overraske, at det var børn fra økonomisk velstillede familier, hvor der var en vis tradition for boglig uddannelse, der gennemførte et universitetsstudium.

Af de 10 fysici, der siden blev embedslæger i det »øvrige Danmark «, var de 9 født nord for Kongeåen og kandidater fra Københavns universitet. De var blevet udnævnt til fysici i hertugdømmet Slesvig inden for tidsrummet 1850- 
Slesvigske fysikater

\begin{tabular}{|c|c|c|c|}
\hline & $\begin{array}{l}\text { ved sanitetskol- } \\
\text { legiets oprettelse } \\
\text { i } 1804\end{array}$ & $\begin{array}{l}\text { ved krigs- } \\
\text { udbruddet } \\
1864\end{array}$ & $\begin{array}{c}\text { numme- } \\
\text { rering } \\
1852\end{array}$ \\
\hline \multirow[t]{2}{*}{ I } & Haderslev - - - & Haderslev & 1 \\
\hline & & Gram & 2 \\
\hline II & Aabenraa - - - & - Aabenraa & 3 \\
\hline IV & Sønderborg - - & - Sønderborg & 4 \\
\hline IV & Ærø - - - - & $\begin{array}{l}\text { - Erø } \\
\text { - Tonder }\end{array}$ & $\begin{array}{l}5 \\
6\end{array}$ \\
\hline \multirow[t]{3}{*}{ III } & Tonder - - - - & & \\
\hline & & - Niebøl & 7 \\
\hline & & - Flensborg by & 8 \\
\hline \multirow[t]{3}{*}{$\mathrm{v}$} & Flensborg - - - & Flensborg land & 9 \\
\hline & & - Bredsted & 13 \\
\hline & & - Slesvig & 12 \\
\hline \multirow[t]{3}{*}{ VI } & Slesvig ---- & & \\
\hline & & - Kappel & 10 \\
\hline & & - Ekernforde & 11 \\
\hline \multirow[t]{2}{*}{ VIII } & Ekernførde - - & & \\
\hline & & - Sønder Stapel & 16 \\
\hline VII & Husum - - - - & - Husum & 14 \\
\hline $\mathrm{X}$ & Eidersted --- & - Eidersted & 15 \\
\hline IX & Femern - - - - & - Femern & 17 \\
\hline
\end{tabular}

Her illustreres hvilke fysikatsdistrikter - 11 i alt - der fandtes ved Sanitetskollegiets oprettelse i 1804, og hvorledes nogle siden deltes, således at der i 1864 var 17 fysikater.

1864, og de måtte forlade deres embeder i Slesvig som følge af nederlaget i 1864.

Den 10. slesvigske fysikus, der også bestred en embedslægestilling i det "øvrige Danmark «, havde en mere farverig karriere. Det var Claus Pedersen Elius, der 1764-65 var fysikus i Sønderborg og siden blev fysikus på St. Croix, hvor han døde 1773. Han var født i Sverige, og det er ukendt, hvor han har studeret. ${ }^{132}$

\section{Fysikatsforholdene ved krigsafslutningen i 1864}

Hertugdømmet Slesvig blev i 1864 besat af preusserne og administreret af disse, for i 1867 at blive en provins under kongeriget Preussen. De 17 fysikatsdistrikter forblev dog næsten alle uændrede de første år. Af forandringer kan nævnes, at Frø ikke blev afstået ved krigsafslutningen, hvorfor det som et lægedistrikt blev underlagt Fyns stiftsfysikat. De kongerigske enklaver overfør- 
tes ved nedlæggelsen af Ribe amts søndre lægedistrikt til de fysikater, hvori de var beliggende: Gram, Tønder, Niebøl og Bredsted. Haderslev fysikatsdistrikt reduceredes med 8 sogne syd for Kolding Fjord, som blev tillagt Kolding lægedistrikt under Vejle og Gammel Skanderborg amters fysikatsdistrikt. Øen Femern overførtes administrativt til Holsten, fysikatet blev snart nedlagt og tillagt fysikatsdistriktet på Holstens østkyst, der omfattede byerne Oldenburg, Lütjenburg og Heiligenhafen samt det omliggende landområde, et distrikt der i dansk tid fra 1854 var blevet benævnt 6 . holstenske fysikatsdistrikt. ${ }^{92}$

Af de 17 fysici afskedigedes de 10 af de nye magthavere. 5 fysici fortsatte $i$ deres embeder efter 1864: Ekernførde, Bredsted, Gram, Kappel og Sønderstapel. ${ }^{133}$ Også fysikus på Femern fortsatte indtil 1870, i hvert fald af navn. Fysikus på Ærø fortsatte i embedet indtil 1865.

\section{LITTERATUR}

De i parentes med kursiv anførte forkortelser er benyttet i listen over henvisninger.

Achelis, Thomas Otto: Die Ärzte im Herzogtum Schleswig bis zum Jahre 1804. Kiel 1966. (AchelisÄrzte)

Achelis, Thomas Otto: Haderslev i gamle Dage 1627-1800. Bind 2, 1929. (Achelis-Haderslev)

Achelis, Thomas Otto: Matrikel der schleswigschen Studenten 1517-1864. 3 bind, 1966-67, Gad, København. (Achelis-Studenten)

Boie, Karl: Ein Beitrag zur Besiedelungsfrage Fehmarns durch Dithmarscher. Zeitschrift der Gesellschaft für Schleswig-Holsteiniche Geschichte. Band 63, p. 369-387. (Boie)

Brix, Johannes: Lægevirke i Sønderjylland før 1864. Dansk medicinhistorisk årbog 1980. (Brix)

Chronologische Sammlung der für die Herzogthümer Schleswig und Holstein erlassenen Verordnungen und Verfügungen. (Chron. Samml.)

Dohrn, N.: Die Schleswig-Holsteinische Medicinalverfassung. Heide 1834. (Dohrn)

Flensborg bys historie. 2 bind, København 1953 og 1955. (Flensb. hist.)

Forchhammer, Th.: Sammlung der Gesetze und Verfügungen welche das Medicinalwesen in den Herzogthümern Schleswig und Holstein betreffen. Altona 1824. (Forchhammer)

Graef, Fritz: Flensburger Ärzte und Apoteker im 17. Jahrhundert. 100 Jahre Flensburger Ärzteverein e.V. 1884-1984. (Graef)

Gregersen, H.V.: Reformationen i Senderjylland. Historisk Samfund, Aabenraa 1986. (GregersenReform.)

Gregersen, H.V.: Slesvig og Holsten før 1830. Danmarks historie. Politikens forlag 1981. (GregersenSl.Holst.)

Gotfredsen, Edv.: Medicinens Historie. 2. udg. 1964. (Gotfredsen)

Grodum, Tage: Embedslægevæsenet og fysici i hertugdømmet Slesvig indtil 1864. Dansk medicinhistorisk årbog 1986. (Grodum-Slesvig)

Grodum, Tage: Embedslægevæsenet og fysici i hertugdømmerne Holsten og Lauenburg indtil 1864. Dansk medicinhistorisk årbog 1987. (Grodum-Holsten)

Grodum, Tage: Medicinallovgivning og -lovsamlinger i hertugdømmerne Slesvig og Holsten med saerlig henblik på fysikatsvæesenet. Dansk medicinhistorisk årbog 1988. (Grodum-med.lov)

Hertel, Klaus: Tre store københavnske epidemier. Disputats. FADL's forlag 1979. (Hertel)

Hof- und Staats-Kalender. Samtlige årgange 1734-1864. (Hof og Stat)

Hvidtfeldt, Johan: Den nordslesvigske embedsstand 1770-1840. Sønderjyske Arbøger, 1958. (Hvidtfeldt) 
Ingerslev, Vilhelm: Danmarks Læger og Lagevæsen fra de aldste Tider indtil Aar 1800. 2 Bind, Kjøbenhavn 1873. (Ingerslev)

Jendreycyk, E.: Die Apotheke zu Tönning. Zeitschrift der Gesellschaft für Schleswig-Holsteinische Geschichte. Band 40,1910 p. 285. (Jendreycyk)

Jenner, Harald: Organisation des Gesundheitswesens in Schleswig-Holstein in der ersten Hälfte des 19. Jahrhunderts. Zeitschrift der Gesellschaft für Schleswig-Holsteinische Geschichte. Band 107, 1982 p. 67-112. (Jenner)

Jordan, Karl: Christian-Albrechts-Universität Kiel 1665-1965. Neumünster 1965. (Jordan)

Klockenhoff, Roland: Sylter Landschaftsärzte 1786-1890 und ihre Vorgänger. Nordfriisk Instituut, Bredstedt 1988. (Klockenhoff)

Langenheim, Friedrich: Sammlung der das Medicinalwesen in dem Herzogthum Holstein betreffenden Verordnungen ... Schleswig 1854. (Langenheim)

Lægestand, Den danske. Adskillige udgaver. (Lagestand)

Medicinallovgivning, Den civile, i Kongeriget Danmark med nordlige Bilande og Colonier. Flere værker: C.P. N. Petersen 1833, F.A. Uldall 1863, Joh. Møller 1882. (Med.lovgivn.)

Mittheilungen aus dem Gebiete der Medizin, Chirurgie und Pharmacie. 3. Jahrgang, 1835. (Mittheilungen)

Neues Staatsbürgerliches Magazin. 1834, 2. Band. (Neues Staatsb.Mag.)

Norrie, Gordon: Theatrum-Anatomico-Chirurgicum. Bd. I og Il, København 1931 og 1932. (Norrie)

Provinzial-Handbuch für Schleswig-Holstein und Herzogthum Lauenburg. 1868. (Prov.Handb.)

Rasch, Max: Von den Barbieren, Chirurgen und den ersten gelehrten Medizinern in der Stadt Apenrade. Die Heimat 1951, p. 37-49. (Rasch)

Runge, Johann: Sønderjyden Christian Paulsen. Studieafdelingen ved Dansk Centralbibliotek for Sydslesvig, Flensborg 1981. (Runge)

Smid, Henrich (udi Malmø): En liden Bog om Menniskens Vand $\propto$ anden Naturlig Affgang. Prentet i Lybeck 1557. (Henrich Smid)

Snorrason, Egill: Johann Friedrich Struensee. København 1968. (Snorrason)

Staatsbürgerliches Magazin mit besonderer Rücksicht auf die Herzogthümer Schleswig, Holstein und Lauenburg. Herausgegeben von Dr. N. Falck. (Staatsb.Mag.)

Staats-Handbuch für die Herzogtümer Schleswig-Holstein auf das Jahr 1849. (Staats-Handb.)

Sønderjyllands Historie fremstillet for det danske Folk. (5 bind), Bd. III og IV, København 193042. (Sdr.jyll.Hist.)

Trap, J.P.: Statistisk-topographisk Beskrivelse af Hertugdemmet Slesvig. Kjøbenhavn 1864, Almindelig og Speciel Deel. (Trap-Slesvig)

Winkle, Stefan: Johann Friedrich Struensee. Stuttgart 1983. (Winkle)

250 Jahre Christianeum 1738-1988. Des Königs Schule spricht Latein. Katalog zur Ausstellung. Altona Museum 1988. (Christianeum)

\section{HENVISNINGER}

1. Dohrn p. 36 ff, Med.lovgivn. (Uldall 1. Bd.)

2. Gotfredsen p. 179, Ingerslev I p. 52

3. Heinrich Smid, Fortalen p. 3

4. Ingerslev I p. 105-106

5. Ingerslev I p. 106, p. 292-293

6. Ingerslev I p. 191

7. Ingerslev I p. $99-102$, p. 186

8. Ingerslev I p. 106 og p. 192

9. Ingerslev I p. $165-167$ og p. 186

10. Gotfredsen p. 234 og p. 584

11. Gregersen-Reform. p. 219 og p. $227 \mathrm{ff}$

12. Gregersen-Sl.Holst., Sdr.jyll.Hist. 
13. Achelis-Ärzte p. 16, Brix p. 66, Graef p. 14, Flensb.hist. 1. bd. p. 294

14. Achelis-Ärzte p. 33

15. Jendreycyk p. 285 , Achelis-Ärzte p. 16 og p. 43

16. Achelis- $\ddot{\text { rzte p. }} 16 \mathrm{og}$ p. 28

17. Achelis-Ärzte p. 16 og p. 29

18. Jordan p. $15 \mathrm{ff}$

19. Jordan p. $9 \mathrm{ff}$

20. Gregersen-SI.Holst. p. 372 ff, Sdr.jyll.Hist. III

21. Dohrn p. 43, Brix p. 67 , Hvidtfeldt p. 191

22. Dohrn p. 43 , Brix p. 13

23. Sdr.jyll.Hist. III p. 362, Staats-Handb. p. 276, Christianeum p. 73, p. 122, p. 157 ff, p. 165

24. Gregersen-Sl.Holst. p. 393 ff, Sdr.jyll.Hist. III

25. Sdr.jyll.Hist. III p. 391 og IV p. 31-32, Jordan p. 25, Gregersen-Sl.Holst. p. 423, Runge p. 276 og p. 325.

26. Sdr.jyll.Hist. III p. 398, Achelis-Ärzte p. 7

27. Gregersen-Sl.Holst., Sdr.jyll.Hist. III og IV

28. Dohrn p. 45

29. Gotfredsen p. 292 og p. 580 , Hertel p. $25 \mathrm{ff}$

30. Dohrn p. 45-52, Langenheim p. $27 \mathrm{ff}$, Forchhammer p. $15 \mathrm{ff}$

31. Gotfredsen p. 586, Hertel p. 27

32. Brix p. 15-16, Forchhammer p. XXIV

33. Brix p. 16, Dohrn p. 6

34. Brix p. 16

35. Brix p. 16, Langenheim p. 84

36. Brix p. 84

37. Brix p. 85

38. Brix p. 85

39. Brix p. 86, Langenheim p. $32 \mathrm{ff}$

40. Chron.Samml., Forchhammer, Dohrn, Langenheim

41. Grodum-Holsten p. 134 ff

42. Dohrn p. 53

43. Dohrn p. 37 (\$6) og p. $44(\$ 6)$

44. Dohrn p. 140 ff, Staatsb.Mag. 1827, 7. Bd. p. 648, Flensb.hist. 2. bd. p. 92

45. Dohrn p. 37 (\$5) og p. 60 (circ.skriv. 19.8.1823)

46. Dohrn p. 60

47. Dohrn p. 56

48. Dohrn p. 37 (\$7)

49. Dohrn p. 44

50. Dohrn p. $46(\$ 5-6)$ og p. $50(\$ 30-32)$

51. Dohrn p. $37(\$ 9)$

52. Dohrn p. $45-46$ (\$4-5)

53. Dohrn p. 51 ( $\$ 3)$

54. Dohrn p. 56-57

55. Dohrn p. 58

56. Dohrn p. 59

57. Dohrn p. $206 \mathrm{ff}$, Forchhammer p. $222 \mathrm{ff}$, Gotfredsen p. 281

58. Dohrn p. 357-359

59. Dohrn p. 360

60. Dohrn p. 58

61. Dohrn p. 41 ( $\$ 24)$

62. Dohrn p. 45 (\$ 1-2)

63. Dohrn p. 164 (circ.skriv. 16.10.1824)

64. Dohrn p. 38 
65. Dohrn p. 53

66. Dohrn p. 53

67. Dohrn p. 53

68. Dohrn p. 63

69. Dohrn p. 54

70. Dohrn p. $55-56$

71. Dohrn p. 59

72. Snorrason p. $23 \mathrm{ff}$, Winkle p. 45 og p. 455, Neues Staatsb.Mag. p. 920-921, Grodum-med.lov p. $51, \mathrm{p} 62$ og p 76

73. Dohrn p. XV-XVI

74. Mittheilungen p. 111

75. Jenner p. 96

76. Jenner p. 96

77. Dohrn p. 63

78. Dohrn p. 54

79. Trap-Slesvig. Alm. Deel p. 81, Sdr.jyll.Hist. III p. 407

80. Dohrn p. 63

81. Trap-Slesvig. Alm.Deel p. 81.

82. Dohrn p. 63

83. Dohrn p. 63 og p. 66

84. Achelis-Ärzte p. 11, Klockenhoff

85. Achelis-Ärzte p. 11, Dohrn p. 54

86. Dohrn p. 65

87. Dohrn p. 69

88. Hof og Stat

89. Dohrn p. 62

90. Dohrn p. 69

91. Langenheim p. $32 \mathrm{ff}$

92. Langenheim p. $44 \mathrm{ff}$

93. Trap-Slesvig. Alm.Deel p. 60

94. Med.lovgivn. (Uldall Bd. 1 p. 211)

95. Achelis- ̈̈rzte p. 43

96. Rasch p. 42

97. Dohrn p. 63

98. Grodum-Slesvig p. $42-47$

99. Achelis-Ärzte no. 77, Brix no. 27, Achelis-Haderslev p. 284-285, Norrie p. 85

100. Achelis-Ärzte p. 16 og p. 21

101. Rasch p. 42

102. Grodum-Slesvig p. $48-52$

103. Achelis-Ärzte p. 16 og p. 26

104. Trap-Slesvig. Spec.Deel p. 349

105. Langenheim p. 34

106. Grodum-Slesvig p. 55-58

107. Achelis-Ärzte p. 28 (og p. 16)

108. Achelis-Ärzte p. 28

109. Boie

110. Grodum-Slesvig p. 59-60

111. Grodum-Slesvig p. 61-64

112. Achelis-Ärzte no. 139, Achelis-Studenten no. 5163

113. Dohrn p. 64

114. Grodum-Slesvig p. 72-74

115. Grodum-Slesvig p. 65-69

116. Grodum-Slesvig p. 70-72 
117. Achelis-Ärzte no. 32

118. Grodum-Slesvig p. 75-76

119. Grodum-Slesvig p. 75-78

120. Achelis-Ärzte p. 12 (no. 33) og p. 23-24

121. Trap-Slesvig. Spec.Deel p. 511

122. Grodum-Slesvig p. 80-81

123. Med.lovgivn.

124. Grodum-Slesvig p. $82-83$

125. Grodum-Slesvig p. $84-85$

126. Grodum-Slesvig p. 86

127. Grodum-Slesvig p. 88

128. Grodum-Slesvig p. 89

129. Trap-Slesvig. Spec.Deel p. 601

130. Grodum-Slesvig p. 90

131. Grodum-Slesvig p. 87, Lagestand 6. udg. 1891 p. 144, 9. udg. 1915 p. 258

132. Ingerslev II p. 426, Brix no. 64, Grodum-Slesvig p. 70.

133. Prov.Handb. 